\title{
Physicochemical Characterization and Polyphenolic Content of Beninese Honeys
}

\author{
Sênan Christa Lokossou, ${ }^{1,2}$ Fidèle Paul Tchobo, ${ }^{1}$ \\ Hounnankpon Yédomonhan, ${ }^{2}$ and Mohamed Mansourou Soumanou ${ }^{1}$ \\ ${ }^{1}$ Unit of Food and Enzymatic Engineering Research, Polytechnic School of Abomey-Calavi, University of Abomey-Calavi, \\ 01 BP 2009 Cotonou, Benin \\ ${ }^{2}$ Laboratory of Botany and Plant Ecology, Faculty of Sciences and Technologies, University of Abomey-Calavi, \\ 01 BP 4521 Cotonou, Benin
}

Correspondence should be addressed to Fidèle Paul Tchobo; fideletchobo@gmail.com

Received 12 May 2017; Revised 12 July 2017; Accepted 26 July 2017; Published 7 September 2017

Academic Editor: Lillian Barros

Copyright (C) 2017 Sênan Christa Lokossou et al. This is an open access article distributed under the Creative Commons Attribution License, which permits unrestricted use, distribution, and reproduction in any medium, provided the original work is properly cited.

\begin{abstract}
The physicochemical and phytochemical analyses of honeys $(n=50)$ from Sudanese, Sudano-Guinean, and Guinean areas of Benin were investigated. Results showed that dark amber is the dominant color. Moisture content ranged from $15.50 \%$ to $23.50 \%$, and $72 \%$ of honeys respected the Codex Alimentarius recommendation. $\mathrm{pH}$ varied between 2.87 and 6.15, and free acidity ranged from 9.00 to $39.00 \mathrm{meq} / \mathrm{kg}$. Electrical conductivity varied from 0.37 to $1.43 \mathrm{mS} / \mathrm{cm}$. The content in fructose varied from $21.67 \%$ to $94.21 \%$, and proline content ranged between 306.31 and $1187.93 \mathrm{mg} / \mathrm{kg}$. All physicochemical characteristics varied with the areas. A negative correlation was found between $\mathrm{pH}$ and moisture content $(r=-0.55 ; p<0.01)$. A positive correlation was established between $\mathrm{pH}$ and conductivity $(r=0.79 ; p<0.01)$ and between proline and color $(r=0.44 ; p<0.01)$. Total phenolic content varied between 55.97 and $224.99 \mathrm{mg} \mathrm{GAE} / 100 \mathrm{~g}$, and flavonoid content ranged between 1.43 and $29.81 \mathrm{mg}$ CAE/100 g. Flavonoid was positively correlated with color $(r=0.78 ; p<0.01)$ and proline $(r=0.47 ; p<0.01)$. Tukey's test revealed differences between total phenolic and flavonoid contents of honeys from five areas $(p<0.01)$. In general, Sudanese and Sudano-Guinean honeys showed potential toward therapeutic applications because of their high phenolic contents.
\end{abstract}

\section{Introduction}

Honey is a natural sweet substance produced by honeybees, Apis mellifera (Linnaeus, 1758), from the nectar of plants (blossoms), the secretions of living parts of plants, or excretions of plant-sucking insects present on the living parts of plants. The bees collect, transform (by combining them with specific substances of their own), deposit, dehydrate, store, and leave the collected nectar in the honeycomb to ripen and mature [1]. Honey has various nutritional, medicinal, and prophylactic properties provided by its various chemical constituents [2]. Honey has been reported to contain about 200 substances (complex mixture of sugars, but also small amounts of other constituents such as minerals, proteins, vitamins, organic acids, flavonoids, phenolic acids, enzymes, and other phytochemicals) and is considered as an important component of traditional medicine [3]. Its composition is rather variable and depends primarily on its floral origin; however, certain external factors, such as seasonal and environmental factors, as well as processing methods, also play a role $[2,4-8]$. Besides, the quality of honey is mainly determined by its sensorial, chemical, physical, and microbiological characteristics. The major physicochemical quality criteria are moisture content, electrical conductivity, ash content, reducing and nonreducing sugar content, free acidity, diastase activity, and hydroxymethylfurfural content [9].

Elsewhere, it has been demonstrated that some of the constituents present in honey have antioxidant properties. These include phenolic acids and flavonoids [10], certain enzymes (glucose oxidase and catalase) [11], ascorbic acid, proteins, and carotenoids [6]. The botanical origin of honey 
influences its antioxidant activity, while processing, handling, and storage only affect this activity to a minor degree. Several studies have shown that antioxidant activity is strongly correlated with the total phenolic content [12-15].

Benin is subdivided into three phytogeographical areas, each characterized by specific flora [16]. As studies clearly indicate the variation in honey quality with distinct floral origins, this study was undertaken to compare the physicochemical characteristics, as well as total phenolic and flavonoid contents of honeys obtained from different phytogeographical areas of Benin.

\section{Material and Methods}

Benin is subdivided into three phytogeographical areas (Sudanese, Sudano-Guinean, and Guinean). Preliminary investigations showed that Bassila (zone SG1) and N'Dali (zone SG2) in the Sudano-Guinean area, Tanguieta (zone S1) and Kandi in the Sudanese area, and Zogbodomey (zone G) in the Guinean area represent five towns where beekeeping is practiced and high quantities of honey are produced (Figure 1). Fifty samples were collected from these five towns: ten samples per zone. Each phytogeographical area is characterized by its flora [16]. Honeys were collected between March and December 2016 in agreement with honey harvest periods. All samples were kept at $4^{\circ} \mathrm{C}$.

2.1. Physicochemical Properties. Moisture content, $\mathrm{pH}$, acidity, and electrical conductivity were determined by standard methods defined by the International Honey Commission [17]. Moisture content was determined using a honey hand refractometer (Honey Tester 68-92\% N600048 meopta), $\mathrm{pH}$ and free acidity were determined by titration to $\mathrm{pH}$ 8.3, and electrical conductivity was determined using a HANNA DIST2 hand conductometer. Color was determined according to the White [18] method, based on the Pfund indicator calculation. Absorbance was measured at $635 \mathrm{~nm}$ using 50\% filtered honey solutions and the Pfund indicator calculated as $-38.70+371.39 *$ Absorbance.

Sugar content was evaluated through the phenol-sulfuric method developed by Dubois et al. [19]. For each honey solution $(1 \mathrm{~mL}), 0.5 \mathrm{~mL}$ of phenol solution ( $5 \%$ in water) was added, followed by the addition of $2.5 \mathrm{~mL}$ of sulfuric acid. The mixture was then shaken and immediately stored at $25-30^{\circ} \mathrm{C}$ for twenty minutes. Absorbance was subsequently read at $485 \mathrm{~nm}$. Fructose content, expressed in grams per 100 grams, was calculated using a calibration curve prepared from a fructose standard solution, that was analyzed in the same way as the honey samples.

Proline content was determined through the International Honey Commission method [17]. Each honey solution $(0.5 \mathrm{~mL})$ was mixed with $1 \mathrm{~mL}$ of formic acid $(80 \%)$ and $1 \mathrm{~mL}$ of ninhydrin solution (3\% in the ethanol). The mixture was then shaken vigorously for fifteen minutes and placed in a bath containing boiling water for an additional fifteen minutes. Then, the mixture was transferred into a water bath set at $70^{\circ} \mathrm{C}$ for ten minutes. Subsequently, $5 \mathrm{~mL}$ of $50 \%$ 2-propanol solution was added to the mixture, which was then left to cool down. The absorbance was subsequently read at $520 \mathrm{~nm}$. Proline content, expressed in milligrams per kilogram, was calculated using a calibration curve prepared with a proline standard solution, that was analyzed in the same way as the honey samples.

The Folin-Ciocalteu method was used to determine the total phenolic content, as reported by Singleton et al. [20]. Each honey solution was filtered $(0.5 \mathrm{~mL})$ and then mixed with $2.5 \mathrm{~mL}$ of $0.2 \mathrm{~N}$ Folin-Ciocalteu reagent for five minutes, before adding $2 \mathrm{~mL}$ of sodium carbonate. After incubation in the dark for two hours, the absorbance was read at $760 \mathrm{~nm}$. Gallic acid was used to generate the calibration curve. The total phenolic content (TPC) was expressed in milligrams of gallic acid equivalents (GAE) per $100 \mathrm{~g}$ of honey.

Flavonoid content was determined using the colorimetric method described by Ita [21]. Each honey solution (1 mL) was mixed with $0.3 \mathrm{~mL}$ of sodium nitrite solution. After five minutes, $0.5 \mathrm{~mL}$ of aluminum chloride was added. The mixture was then homogenized and left to react for six minutes. Two milliliters of potassium hydroxide (KOH, $1 \mathrm{M})$ solution was subsequently added, and absorbance was read at $510 \mathrm{~nm}$. Catechin was used to produce the calibration curve. Total flavonoid content (TFC) was expressed in milligrams of catechin equivalent (CAE) per $100 \mathrm{~g}$ of honey.

All analyses were carried out in duplicate. Statistical analysis was performed using IBM SPSS (IBM corporation, Java) and Minitab 14 Release (statistical software). Data were subjected to a one-way variance analysis (ANOVA) for mean comparison, and significant interhoneys differences were estimated using the Tukey multiple-range test. The results are expressed as mean \pm standard deviations (SD). Correlations were calculated according to Pearson's test. Differences at $p \leq 0.05$ were considered as statistically significant. The dendrogram was made with Minitab based on Ward algorithm and Euclidean distance.

\section{Results and Discussion}

The physicochemical results obtained for the honeys studied are shown as arithmetical means plus standard deviations in Table 1.

Honey color is the first physical property perceived by the consumer. In this study, honey color varies from $105.03 \pm$ $1.05 \mathrm{~mm}$ Pfund (zone S1) to 752.36.94 $1.05 \mathrm{~mm}$ Pfund (zone SG2). Based on the NC 371-04 [22] classification, samples are classified as either amber honeys (6\%) (Pfund value between 86 and 114) or dark amber honeys (94\%) (Pfund values higher than 114). Honeys from the Sudano-Guinean (N'dali) and Sudanese (Kandi) zones are the darkest. Significant differences are observed between the means obtained from different zones $(p<0.01)$. Delphine and Joseph [23] observed that dark amber is the dominant color for honeys produced in Cameroon. White [4] reported that it is an important parameter to consider when assessing the quality and market value of honey. Lighter honeys are marketed for direct consumption while darker ones, which contain more minerals, have higher market values. According to Reshma et al. [24], the color of honey is closely related to its 


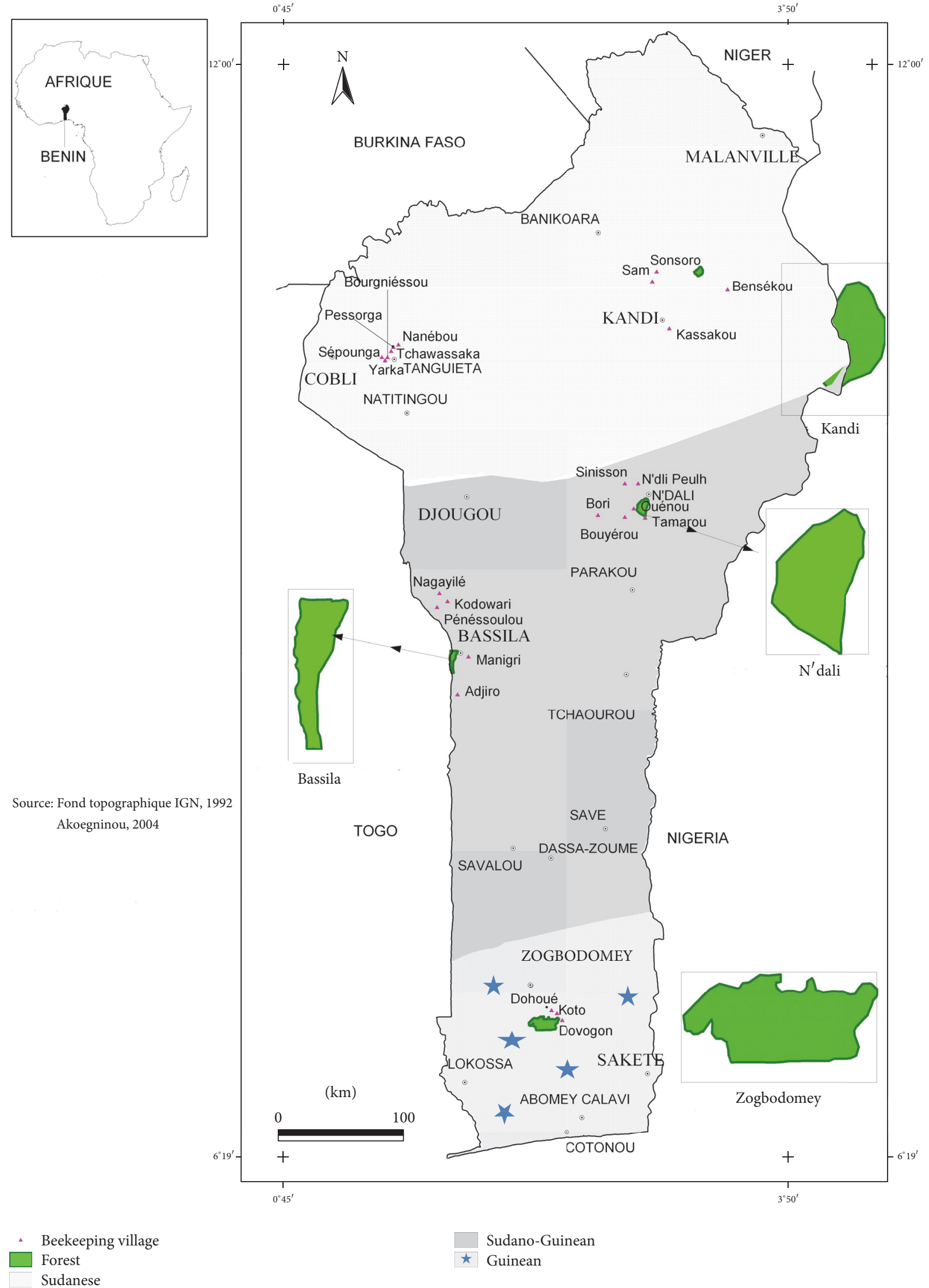

FIgURE 1: Geographical localization of the towns. 


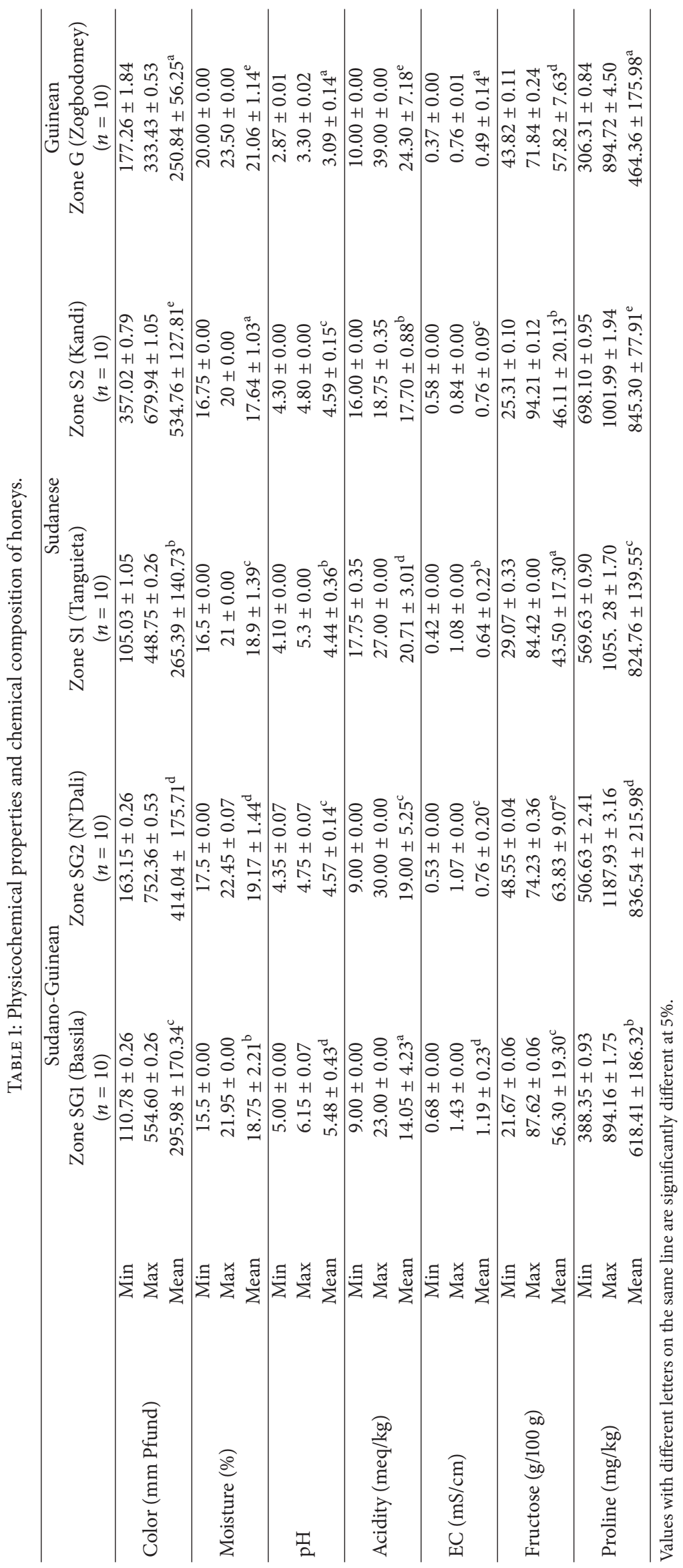


chemical composition and more particularly, to the presence of pigments such as chlorophylls, carotenoids, flavonoids, and derivatives of tannins and polyphenols. Honey color reflects the melliferous flora harvested by bees and varies according to the seasons, the harvesting technics, and the treatment of honey [23]. Many researchers found that honeys with dark color have higher TPC and, consequently, higher antioxidant properties $[13,14]$.

Moisture content is an important quality parameter to take into consideration when evaluating honey quality. The moisture content values obtained ranged from $15.5 \% \pm 0.00 \%$ (zone SG1) to $23.50 \% \pm 0.00 \%$ (zone G). Honeys used in this studies have higher moisture contents than Algeria, Cameroon, and Palestine honeys, whose values range from $13 \%$ to $21.42 \%[23,25,26]$. However, our results are still similar to those obtained (18-23.6\%) from Indian multifloral honeys [24]. These honeys have less moisture content than Nigerian ones (18.30-30.30\%) [27]. Indeed, both the Codex Alimentarius [1] and European Union [9] recommend a humidity value $\leq 20 \%$. High moisture could increase honey fermentation. Sudanese zone samples showed the lowest values (Kandi), whereas the highest values were observed in Guinean honeys. Therefore, Guinean honeys do not meet the requirements and will rapidly ferment.

$\mathrm{pH}$ values varied between $2.87 \pm 0.01$ (zone G) and $6.15 \pm 0.07$ (zone SG1), and free acidity varied from $9.00 \pm$ 0.00 (zone SG1) to $39.00 \pm 0.00$ (zone G) meq/kg. None of the samples exceeded the limit $(\leq 50 \mathrm{meq} / \mathrm{kg})$ considered as the freshness index for all honeys, indicating the absence of any unwanted fermentation [28]. The free acidity values obtained are inferior to those found by Reshma et al. [24] and Meda et al. [29] in India and Burkina Faso, respectively. Similar values were obtained by Achour and Khali [25], as well as Sodré et al. [30], in Algerian and Brazilian honeys, respectively. Guinean zone samples are more acidic than Sudano-Guinean samples. The higher acidity values of Guinean zone honeys imply their good conservation, as it creates an inappropriate environment for bacterial growth. The acidity variation among honey samples is dependent on floral types [31]. However, according to Alvarez-Suarez et al. [6], honey is naturally acidic, regardless of its geographical origin. A negative correlation was found between $\mathrm{pH}$ and moisture content $(r=-0.55 ; p<0.01)$. Therefore, honeys with high moisture contents also display low $\mathrm{pH}$. This relation contributes to the good conservation of moist honeys.

Electrical conductivity (EC) of honey is proportional and shows a linear relation, with ashes content. According to Estevinho et al. [32], while the ashes content reflects the quantity of inorganic residues after carbonization, the conductivity reflects the amount of organic and inorganic ionizable substances. The EC values of honeys varied between $0.37 \pm 0.00$ (zone $G$ ) and $1.43 \pm 0.00 \mathrm{mS} / \mathrm{cm}$ (Zone 1 ). Means are significantly different $(p<0.01)$ and indicate high EC of Sudano-Guinean honeys (Bassila) and low values for Guinean samples. These results are in the same range $(0.24-1.57 \mathrm{mS} / \mathrm{cm})$ than those found by Adenekan et al. [33] and Mekious et al. [34]. Additionally, there is a correlation between $\mathrm{pH}$ and electrical conductivity $(r=0.79 ; p<0.01)$.
Sugar content, expressed in percentage of fructose $(y=$ $\left.0.0051 x-0.00009 ; R^{2}=0.999\right)$, varied from $21.67 \% \pm 0.06 \%$ to $94.21 \% \pm 0.12 \%$. Sugar content varied considerably according to zones $(p<0.01)$, but the samples obtained from the Sudano-Guinean (N'Dali) and Guinean zones showed particularly high qualities in terms of sugar content. Proline contents $\left(y=0.0241 x+0.0005 ; R^{2}=0.999\right)$ varied from $306.31 \pm 0.84$ to $1187.93 \pm 3.16 \mathrm{mg} / \mathrm{kg}$. Proline is considered as the main amino acid in honey, and its value must be superior to $180 \mathrm{mg} / \mathrm{kg}$. The amount of proline is an indicator of purity, and its level decreases significantly in soiled honeys. Content of proline varied significantly among zones $(p<0.01)$. The higher values were obtained from Sudanese (Kandi) and Sudano-Guinean (N'Dali) samples. Values of proline content measured in this study are higher than those obtained from Turkish honeys [35] but range between 169 and $2169 \mathrm{mg} / \mathrm{kg}$ obtained by Meda et al. [10] and Djossou et al. [36]. The level of proline has been reported to vary according to the honey flora [37]. Positive correlations were found between proline and color $(r=0.44 ; p<0.01)$.

Polyphenols are molecules displaying antioxidant properties. These molecules are paramount toward conferring medicinal properties to honeys. Various floral honeys with high polyphenol contents are consumed as medicinal products [35]. Antioxidants, for example, play an important role in food preservation and in human health, by combating damage caused by oxidizing agents such as oxygen.

TPC of honeys varied between $55.97 \pm 0.00$ and $224.99 \pm$ $0.78 \mathrm{mg}$ GAE$/ 100 \mathrm{~g}$ of honey. Honeys from the Sudanese zone have higher TPC values than honeys from the Guinean and Sudano-Guinean zones (Figure 2(a)). The TPC values measured in this study are higher than those obtained $(16.02-120 \mathrm{mg} / 100 \mathrm{~g})$ by Reshma et al. [24], Can et al. [35], and Buba et al. [38] but are similar to the results reported by Djossou et al. [36] and Ouchemoukh et al. [39]. TFC of honeys $\left(y=10.105 x-0.1569 ; R^{2}=0.9989\right)$ ranged between $1.43 \pm 0.00$ and $29.81 \pm 0.07 \mathrm{mg}$ CAE $/ 100 \mathrm{~g}$ of honey. Beninese honeys contain higher flavonoid levels than Cuban (1.09-2.52 mg QE/100 g) and Bangladeshi (1.15-11.67 CAE/100 g) ones [6, 40]. Honeys from the Guinean area show the lowest values of flavonoid content (Figure 2(b)). Tukey's test revealed differences between phenolic and flavonoid contents across the five zones $(p<0.01)$. Correlations were found between flavonoid and proline contents $(r=0.47 ; p<0.01)$ and between flavonoid content and color $(r=0.78 ; p<0.01)$. The darker honeys display the highest antioxidant properties and the highest phenolic, flavone, and flavonol contents [41].

For $50 \%$ similarity, the dendrogram shows 5 clusters (Figure 3), whose characteristics are presented in Table 2. This classification shows that most of the Sudanese area honeys do not have any dominant characteristic. These samples are very scattered across the clusters. In general, Sudanese zone honeys have high total phenolic and flavonoid contents (Clusters 2 and 5). Guinean honeys are clearly characterized by low proline and polyphenolic contents (Cluster 3). Sudano-Guinean samples show high contents in proline and flavonoid (Cluster 2 and Cluster 4). Hence, Sudanese 


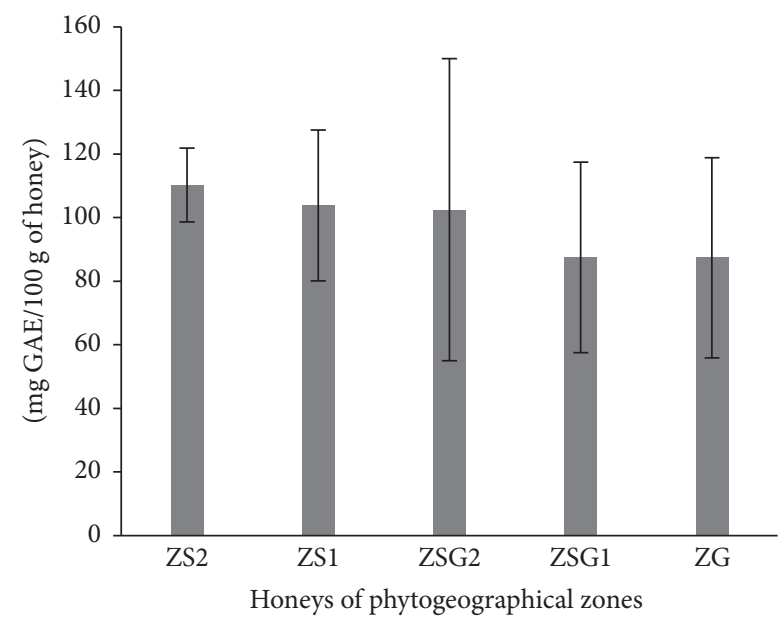

(a)

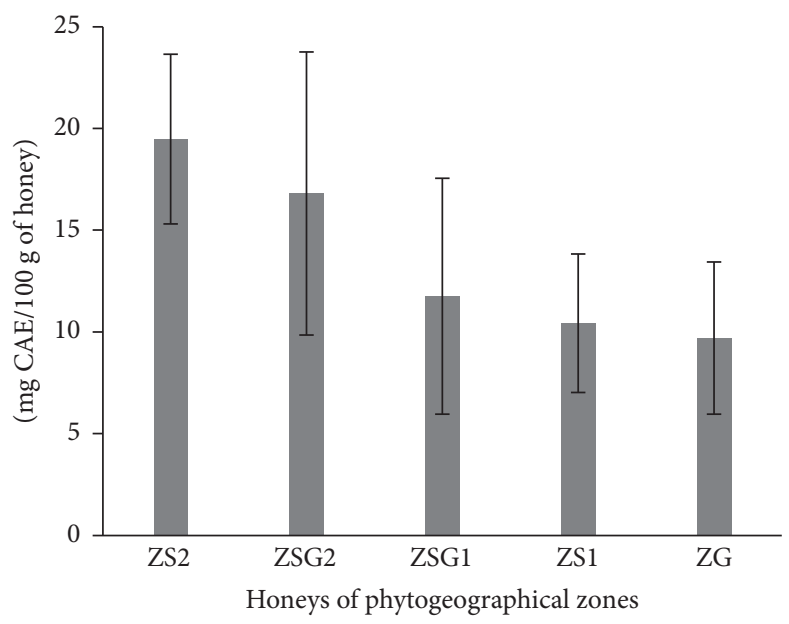

(b)

Figure 2: (a) Means of total phenolic content and (b) means of flavonoids content.

TABLE 2: Clustering of samples.

\begin{tabular}{|c|c|c|c|c|}
\hline & Characteristics & $\begin{array}{c}\text { Number of } \\
\text { samples }\end{array}$ & Samples & Representative zones \\
\hline \multirow[t]{2}{*}{ Cluster 1} & \multirow[t]{2}{*}{ None } & \multirow[t]{2}{*}{15} & \multirow[t]{2}{*}{$\begin{array}{c}\text { B1, B6, N5, N6, N9, T5, T6, T7, T9, T10, } \\
\text { K2, K8, K9, K10, Z6 }\end{array}$} & $\begin{array}{c}\text { ZS: } 50 \% \\
\text { ZSG: } 25 \%\end{array}$ \\
\hline & & & & ZG: $10 \%$ \\
\hline \multirow{4}{*}{ Cluster 2} & (i) Darkest & \multirow{4}{*}{12} & \multirow{4}{*}{$\begin{array}{c}\mathrm{B} 2, \mathrm{~B} 5, \mathrm{~B} 9, \mathrm{~N} 3, \mathrm{~N} 4, \mathrm{~N} 7, \mathrm{~K} 1, \mathrm{~K} 3, \mathrm{~K} 4, \mathrm{~K} 5, \\
\mathrm{~K} 6, \mathrm{~K} 7\end{array}$} & \multirow{4}{*}{$\begin{array}{l}\text { ZS: } 30 \% \\
\text { ZSG: } 30 \%\end{array}$} \\
\hline & (ii) High $\mathrm{pH}$ & & & \\
\hline & (iii) High conductivity & & & \\
\hline & (iv) High flavonoid content & & & \\
\hline \multirow{3}{*}{ Cluster 3} & (i) Low proline content & \multirow{3}{*}{16} & \multirow{3}{*}{$\begin{array}{c}\mathrm{B} 3, \mathrm{~B} 4, \mathrm{~B} 7, \mathrm{~B} 8, \mathrm{~B} 10, \mathrm{~N} 1, \mathrm{~N} 10, \mathrm{~T} 8, \mathrm{Z1}, \mathrm{Z2}, \\
\mathrm{Z} 3, \mathrm{Z} 4, \mathrm{Z} \text {, Z8, Z9, Z10 }\end{array}$} & ZS: 5\% \\
\hline & (ii) Low phenolic content & & & ZSG: 35\% \\
\hline & & & & ZG: $80 \%$ \\
\hline \multirow{3}{*}{ Cluster 4} & (i) High sugar content & \multirow{3}{*}{2} & \multirow{3}{*}{$\mathrm{N} 2, \mathrm{~N} 8$} & \multirow{3}{*}{ ZSG: $10 \%$} \\
\hline & (ii) High proline content & & & \\
\hline & (iii) Low moisture & & & \\
\hline \multirow{2}{*}{ Cluster 5} & (i) Lightest & \multirow{2}{*}{5} & \multirow{2}{*}{$\mathrm{T} 1, \mathrm{~T} 2, \mathrm{~T} 3, \mathrm{~T} 4, \mathrm{Z} 7$} & ZS: $20 \%$ \\
\hline & (ii) High phenolic content & & & ZG: $10 \%$ \\
\hline
\end{tabular}

ZS: Sudanese zone; ZSG: Sudano-Guinean zone; ZG: Guinean zone. B: Bassila; N: N’Dali; K: Kandi; T: Tanguieta; Z: Zogbodomey.

and Sudano-Guinean honeys are promising for potential therapeutic applications because of their high total phenolic and flavonoid contents.

\section{Conclusions}

Physicochemical characteristics as well as total phenolic and flavonoid contents of honeys obtained from the three phytogeographical zones of Benin were compared in this study. The physicochemical characteristics show that these honeys are in agreement with the requirements set by the European Community and Codex Alimentarius Standards. Sudanese and Sudano-Guinean honeys are richer in phenolic compounds and proline than Guinean honeys. These results prove that specific areas and flora have a high impact on honey compositions. Additionally, honeys from the Sudanese and Sudano-Guinean areas show very interesting properties toward potential therapeutic applications. Overall, the influence of each phytogeographical area on honey composition is well-known, as well as the richness in polyphenols of Beninese honeys. 


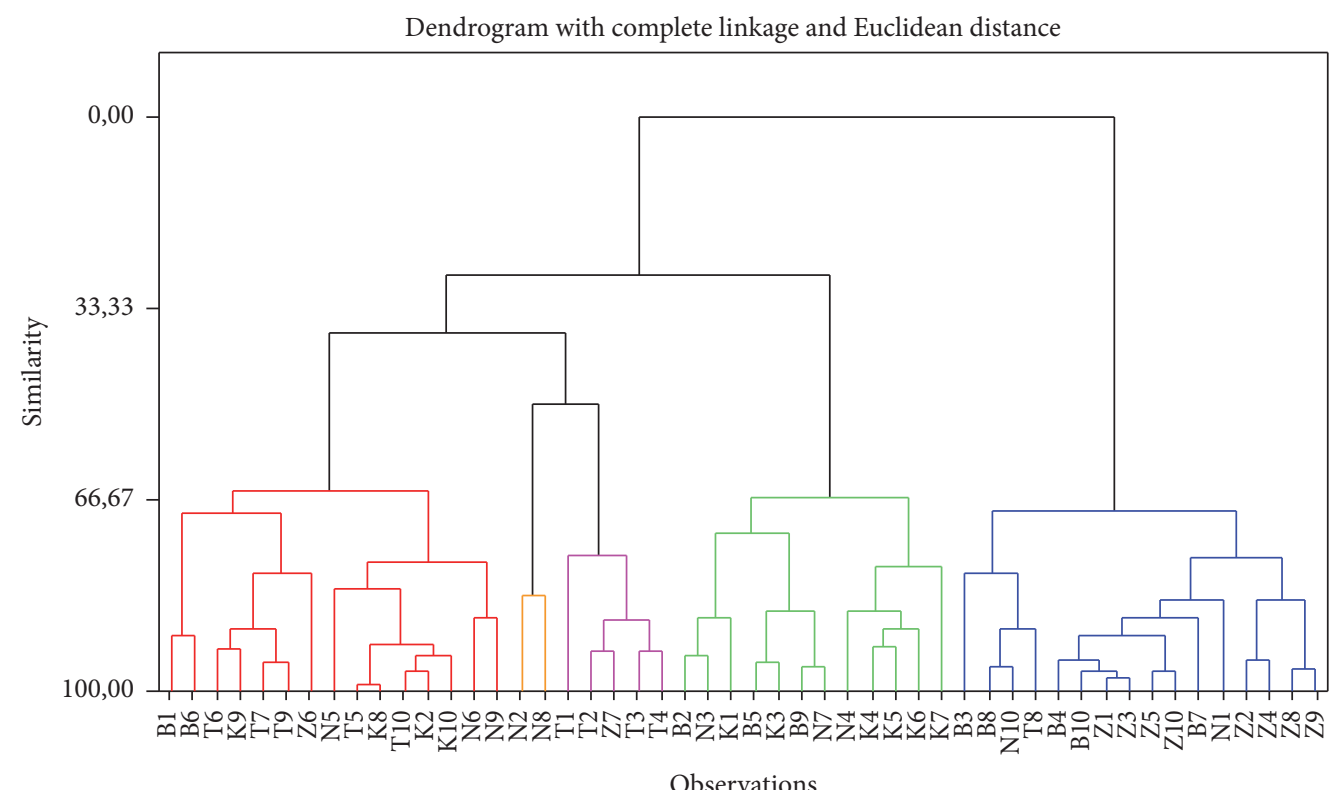

Figure 3: Classification of honeys.

\section{Conflicts of Interest}

The authors declare that there are no conflicts of interest regarding the publication of this paper.

\section{Acknowledgments}

The authors would like to acknowledge the major contribution of Sênan Christa Lokossou, Ph.D. student, in this work.

\section{References}

[1] Commission du Codex Alimentarius, Rapport de la septième session du comité du Codex sur les sucres, Vingt-quatrième session, Genève, p. 35, 2001.

[2] M. Solayman, M. A. Islam, S. Paul et al., "Physicochemical properties, minerals, trace elements, and heavy metals in honey of different origins: a comprehensive review," Comprehensive Reviews in Food Science and Food Safety, vol. 15, no. 1, pp. 219233, 2016.

[3] J. W. White, "Composition of honey", in Honey: A Comprehensive Survey, E. Crane, Ed., pp. 157-158, Heinemann, London, 1979.

[4] J. W. White, Physical characteristics of honey, Survey, Heinemann, London, 1975.

[5] C. Cordella, J.-F. Antinelli, C. Aurieres, J.-P. Faucon, D. CabrolBass, and N. Sbirrazzuoli, "Use of differential scanning calorimetry (DSC) as a new technique for detection of adulteration in honeys. 1. Study of adulteration effect on honey thermal behavior," Journal of Agricultural and Food Chemistry, vol. 50, no. 1, pp. 203-208, 2002.

[6] J. M. Alvarez-Suarez, S. Tulipani, D. Díaz et al., "Antioxidant and antimicrobial capacity of several monofloral Cuban honeys and their correlation with color, polyphenol content and other chemical compounds," Food and Chemical Toxicology, vol. 48, no. 8-9, pp. 2490-2499, 2010.
[7] E. Mbogning, J. Tchoumboue, F. Damesse, M. Sanou Sobze, and A. Canini, "Caractéristiques physico-chimiques des miels de la zone Soudano-guinéenne de l'Ouest et de l'Adamaoua Cameroun," Tropicultura, vol. 3, pp. 168-175, 2011.

[8] L. S. Chua and N. A. Adnan, "Biochemical and nutritional components of selected honey samples," Acta Scientiarum Polonorum, Technologia Alimentaria, vol. 13, no. 2, pp. 169-179, 2014.

[9] European Union Commission, "Council directive 2001/110/EC of 20 December 2001 relating Honey," Official Journal of European Community, vol. L10, pp. 47-52, 2001.

[10] A. Meda, C. E. Lamien, M. Romito, J. Millogo, and O. G. Nacoulma, "Determination of the total phenolic, flavonoid and proline contents in Burkina Fasan honey, as well as their radical scavenging activity," Food Chemistry, vol. 91, no. 3, pp. 571-577, 2005.

[11] P. C. Molan and J. A. Betts, "Clinical usage of honey as a wound dressing: an update," Journal of Wound Care, vol. 13, no. 9, pp. 353-356, 2004.

[12] A. M. Aljadi and M. Y. Kamaruddin, "Evaluation of the phenolic contents and antioxidant capacities of two Malaysian floral honeys," Food Chemistry, vol. 85, no. 4, pp. 513-518, 2004.

[13] G. Beretta, P. Granata, M. Ferrero, M. Orioli, and R. M. Facino, "Standardization of antioxidant properties of honey by a combination of spectrophotometric/fluorimetric assays and chemometrics," Analytica Chimica Acta, vol. 533, no. 2, pp. 185191,2005

[14] M. Blasa, M. Candiracci, A. Accorsi, M. P. Piacentini, M. C. Albertini, and E. Piatti, "Raw Millefiori honey is packed full of antioxidants," Food Chemistry, vol. 97, no. 2, pp. 217-222, 2006.

[15] A. M. M. De Almeida, M. B. S. Oliveira, J. G. Da Costa, I. B. Valentim, and M. O. F. Goulart, "Antioxidant capacity, physicochemical and floral characterization of honeys from the northeast of Brazil," Revista Virtual de Quimica, vol. 8, no. 1, pp. 57-77, 2016.

[16] A. Akoègninou, W. J. Van der Burg, and L. J. G. Van der Maesen, Flore Analytique du Bénin, Backhuys Publishers, 2006. 
[17] "International Honey Commission, Harmonised methods of the international honey commission, p. 62, 2002".

[18] J. W. White, "Instrumental color classification of honey: collaborative study," Journal of the AOAC, vol. 67, pp. 1129-1131, 1984.

[19] M. Dubois, K. A. Gilles, J. K. Hamilton, P. A. Rebers, and F. Smith, "Colorimetric method for determination of sugars and related substances," Analytical Chemistry, vol. 28, no. 3, pp. 350356, 1956.

[20] V. L. Singleton, R. Orthofer, and R. M. Lamuela-Raventós, "Analysis of total phenols and other oxidation substrates and antioxidants by means of folin-ciocalteu reagent," Methods in Enzymology, vol. 299, pp. 152-178, 1999.

[21] B. N. Ita, "Antioxidant activity of honey samples from the southern rainforest and northern savannah ecosystems in Nigeria," International Journal of Pharmaceutical Sciences and Research, vol. 2, no. 8, pp. 2115-2120, 2011.

[22] NC 371-04, Cuban Standard. Bee honey, specifications, p. 12, 2004.

[23] D. N. Delphine and T. Joseph, "Palynological and physicochemical characterization of honey in the Sudano-Guinean zone of Cameroon," Food and Nutrition Sciences, vol. 06, no. 15, 12 pages, 2015.

[24] M. V. Reshma, S. Shyma, T. M. George, A. V. Rishin, K. C. Ravi, and L. Shilu, "Study on the physicochemical parameters, phenolic profile and antioxidant properties of Indian honey samples from extrafloral sources and multi floral sources," International Food Research Journal, vol. 23, no. 5, pp. 20212028, 2016.

[25] H. Y. Achour and M. Khali, "Composition physicochimique des miels algériens. Détermination des éléments traces et des éléments potentiellement toxiques," Afrique Science, vol. 10, no. 2, pp. 127-136, 2014.

[26] A. Abdulkhaliq and K. M. Swaileh, "Physico-chemical properties of multi-floral honey from the West Bank, Palestine," International Journal of Food Properties, vol. 20, no. 2, pp. 447454, 2017.

[27] J. Kayode and S. D. Oyeyemi, “"Physico-chemical study and analysis of pollen grains in some commercial honey samples found in Ondo State, Nigeria," International Journal of Basic and Applied Science, vol. 3, no. 2, pp. 63-73, 2014.

[28] M. S. Finola, M. C. Lasagno, and J. M. Marioli, "Microbiological and chemical characterization of honeys from central Argentina," Food Chemistry, vol. 100, no. 4, pp. 1649-1653, 2007.

[29] A. Meda, C. E. Lamien, J. Millogo, M. Romito, and O. G. Nacoulma, "Physicochemical analyses of Burkina Fasan honey," Acta Veterinaria Brno, vol. 74, no. 1, pp. 147-152, 2005.

[30] G. S. Sodré, L. C. Marchini, A. C. D. C. C. Moreti, I. P. Otsuk, and C. A. L. de Carvalho, "Physico-chemical characteristics of honey produced by Apis mellifera in the Picos Region, State of Piauí, Brazil," Revista Brasileira de Zootecnia, vol. 40, no. 8, pp. 1837-1843, 2011.

[31] E. Anklam, "A review of the analytical methods to determine the geographical and botanical origin of honey," Food Chemistry, vol. 63, no. 4, pp. 549-562, 1998.

[32] M. Estevinho, M. Vázquez-Tato, J. Seijas, and X. Feás, "Palynological, physicochemical, and microbiological attributes of organic lavender (Lavandula stoechas) honey from Portugal," Acta Alimentaria, vol. 42, no. 1, pp. 36-44, 2013.

[33] M. O. Adenekan, B. A. Adelekan, and F. I. Oluwatoyiunbo, "Physicochemical and vitamin constituents of honey samples obtained from different agro-ecological Zones of Nigeria,"
Journal of Agriculture and Veterinary Sciences, vol. 7, no. 2, pp. 28-43, 2015.

[34] S. Mekious, Z. Houmani, E. Bruneau, C. Masseaux, A. Guillet, and T. Hance, "Caractérisation des miels produits dans la région steppique de Djelfa en Algérie," Biothechnologie, Agronomie, Société et Environnement, vol. 19, no. 3, pp. 221-231, 2015.

[35] Z. Can, O. Yildiz, H. Sahin, E. Akyuz Turumtay, S. Silici, and S. Kolayli, "An investigation of Turkish honeys: their physicochemical properties, antioxidant capacities and phenolic profiles," Food Chemistry, vol. 180, pp. 133-141, 2015.

[36] J. A. Djossou, F. P. Tchobo, H. Yédomonhan, A. G. Alitonou, M. M. Soumanou, and H. Yédomonhan, "Evaluation des caractéristiques physico-chimiques des miels commercialisés à Cotonou," Tropicultura, vol. 31, no. 3, pp. 163-169, 2013.

[37] J. F. Cotte, H. Casabianca, B. Giroud, M. Albert, J. Lheritier, and M. F. Grenier-Loustalot, "Characterization of honey amino acid profiles using high-pressure liquid chromatography to control authenticity," Analytical and Bioanalytical Chemistry, vol. 378, no. 5, pp. 1342-1350, 2004.

[38] F. Buba, A. Gidado, and A. Shugaba, "Analysis of biochemical composition of honey samples from North-East Nigeria," Biochemistry \& Analytical Biochemistry, vol. 2, no. 3, 7 pages, 2013.

[39] S. Ouchemoukh, N. Amessis-Ouchemoukh, M. GómezRomero et al., "Characterisation of phenolic compounds in Algerian honeys by RP-HPLC coupled to electrospray time-offlight mass spectrometry," LWT - Food Science and Technology, 2016.

[40] M. Moniruzzaman, C. Yung An, P. V. Rao et al., "Identification of phenolic acids and flavonoids in monofloral honey from bangladesh by high performance liquid chromatography: determination of antioxidant capacity," BioMed Research International, vol. 2014, Article ID 737490, 11 pages, 2014.

[41] J. A. Pontis, L. A. M. A. da Costa, S. J. R. da Silva, and A. Flach, "Color, phenolic and flavonoid content, and antioxidant activity of honey from Roraima, Brazil," Food Science and Technology, vol. 34, no. 1, pp. 69-73, 2014. 

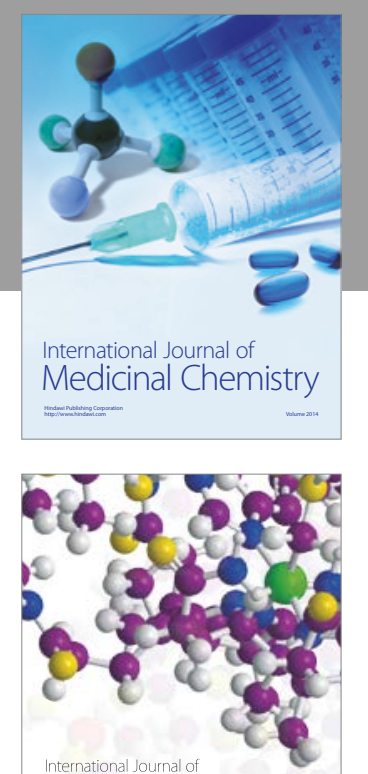

Carbohydrate Chemistry

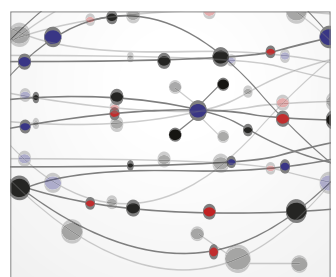

The Scientific World Journal
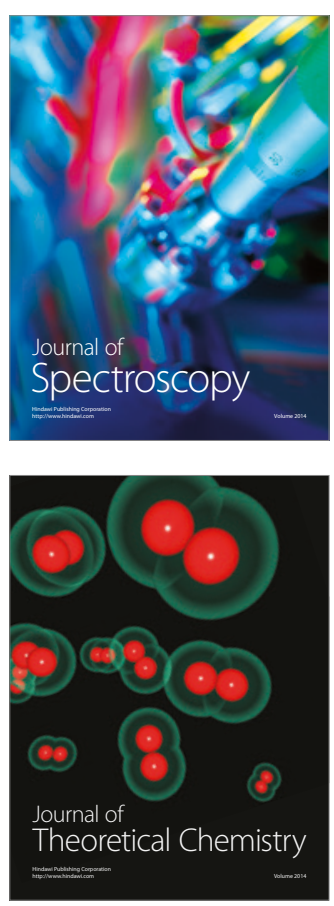
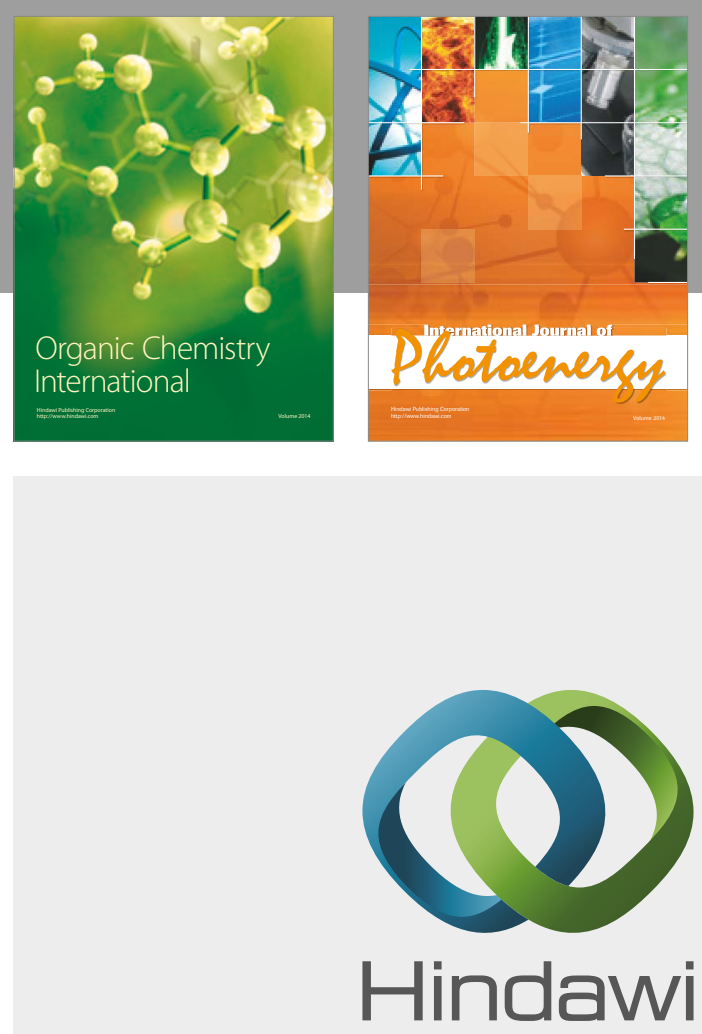

Submit your manuscripts at

https://www.hindawi.com

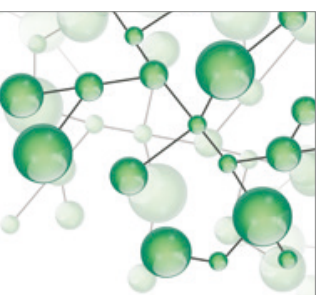

International Journal of

Inorganic Chemistry

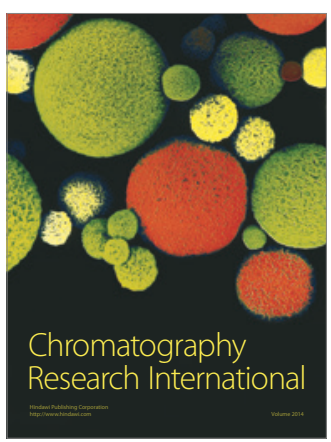

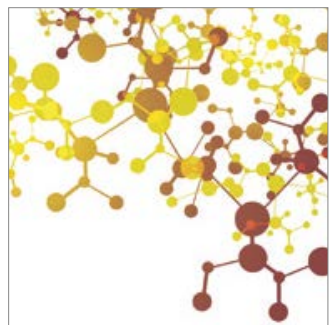

Applied Chemistry
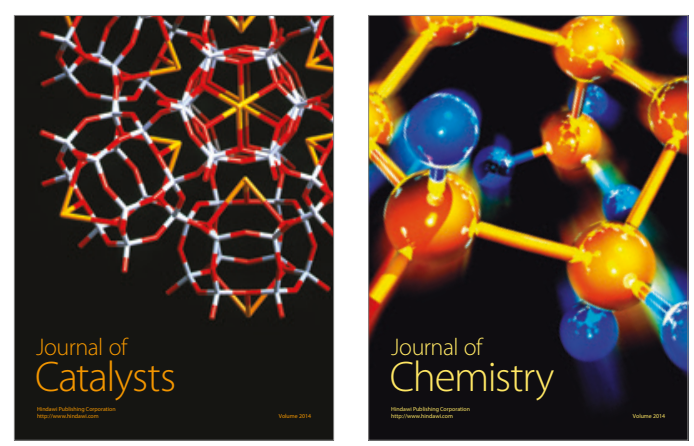
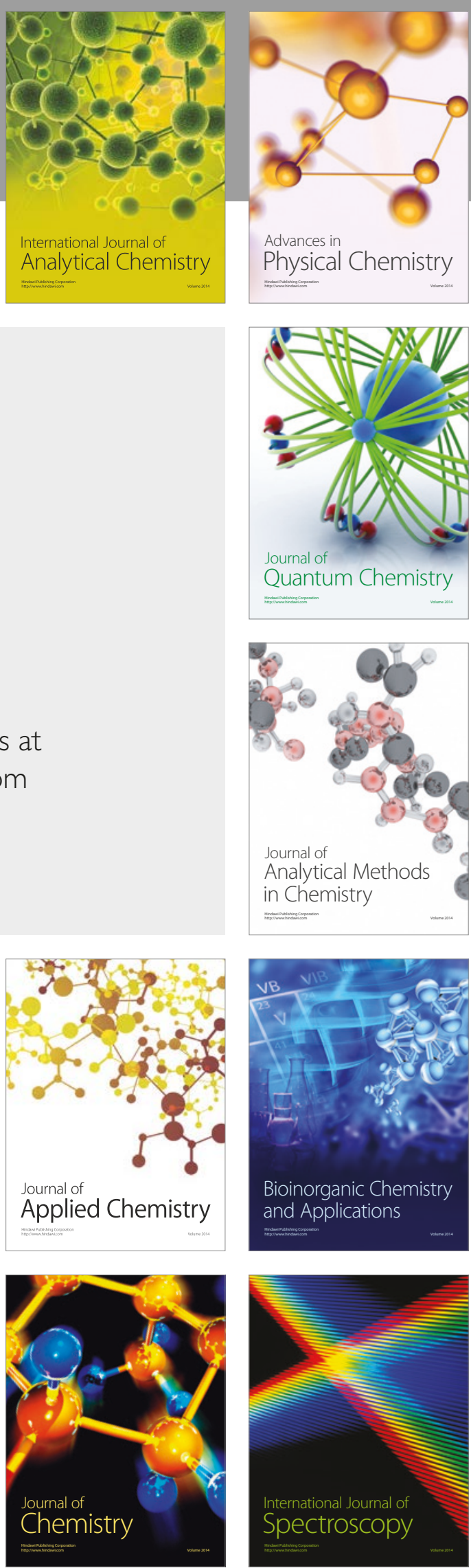